\title{
English language teaching in Bangladesh today: Issues, outcomes and implications
}

\author{
Mohammad Mosiur Rahman ${ }^{1 *}$ (D), Md Shaiful Islam²,3, Abdul Karim ${ }^{4,5}$, Takad Ahmed Chowdhury ${ }^{6,7}$, \\ Muhammad Mushfiqur Rahman ${ }^{8,9}$, Prodhan Mahbub Ibna Seraj ${ }^{2}$ and Manjet Kaur Mehar Singh'
}

\author{
* Correspondence: mosiurbhai2.0@ \\ gmail.com \\ ${ }^{1}$ School of Languages, Literacies \\ and Translation, Universiti Sains \\ Malaysia, Penang, Malaysia \\ Full list of author information is \\ available at the end of the article
}

\begin{abstract}
Given the significance of English in the global world, English language teaching in Bangladesh has become subject to a supreme concern in maintaining economic growth and developing a skilled workforce. In this article, several barriers have been discussed based on a critical analysis of published materials. This review article covers several key issues such as the status of English in the country; English in education policies; factors affecting the implementation of communicative language teaching curriculum, method, and materials in Bangladesh; validity of the current assessment and its washback effect on English language teaching in Bangladesh; and current situation of teachers' professional development. The article concluded with language policy and planning implications for policymakers, curriculum and material developers, public exams' test-setters, and future English teacher training programmes, keeping the overall development of ELT in Bangladesh in mind.
\end{abstract}

Keywords: English in Bangladesh, English in education policy, CLT curriculum, CLT methodology, CLT textbook and assessment reform, Validity and washback effect of testing, Teacher education, English language teaching in Bangladesh

\section{Introduction}

A World Bank report that was made public in 2016 identifies Bangladesh as a lower middle-income country, considering the nation's consistent growth in the last decade (Rahman \& Pandian, 2018a, 2018b). The role of English is undeniable in maintaining this growth and developing skilled workforces, who are globally compatible (Hamid, 2010). Therefore, bearing the economic interest in mind, improvement in English language teaching and learning has become the prior concern. Although numerous measures have been taken in recent years to standardise English language teaching (ELT) in the country, the outcomes are depressing (Ali \& Walker, 2014; Hamid \& Baldauf, 2008). To illustrate, multifaceted problems such as the politically motivated decision in lowering the status and use of English in Bangladesh since the independence (Chowdhury \& Kabir, 2014), inconsistent language in education policies (Rahman \& Pandian, 2018a), implementation of communicative language teaching (CLT) curriculum, teaching method and instructional materials in practice (Rahman, Pandian, \& Kaur, 2018a), implementation of assessment reform (Al Amin \& Greenwood, 2018a; Ali, Hamid, \& Hardy, 2018), and language teachers' professional development (Karim

(C) The Author(s). 2019 Open Access This article is distributed under the terms of the Creative Commons Attribution 4.0 International License (http://creativecommons.org/licenses/by/4.0/), which permits unrestricted use, distribution, and reproduction in any medium, provided you give appropriate credit to the original author(s) and the source, provide a link to the Creative Commons license, and indicate if changes were made. 
\& Mohamed, 2019) are the most significant drawbacks that preclude ELT to meet national expectation in Bangladesh.

Against the backdrop of these problems in the landscape of ELT in Bangladesh, based on the published materials in the context, this article critically analyses the historical, political, and social conditions of English in Bangladesh in the first phase. Secondly, the article scrutinises the existing status of English language education in national education policies in Bangladesh. Thirdly, it draws attention on the factors affecting the implementation of CLT curriculum, method, and materials. Furthermore, the article also assesses the validity of reformed high-stakes assessment in Bangladesh and its washback effect on teaching. Finally, the article explicates the deficiencies of existing teacher development programmes in language teachers' capacity building. The article concludes with several implications and recommendations to improve the situation of ELT in the country and specifically the probable solutions to overcome the discussed problems.

\section{English in Bangladesh: a socio-historical and political perspective}

Since language is an essential component for the construction of a unique cultural life of a region, it is essential to reflect on the historical background of languages in Bangladesh and explore how the current linguistic reality has emerged. Bangladesh is a small and densely populated country in South Asia with a land area of $147,000 \mathrm{~km}^{2}$ and a population of 160 million. Of the total population, 34\% of people live in urban areas, and urban migration is increasing day by day (World Bank, n.d.). The ethnicity of $98 \%$ of the people of Bangladesh is Bengali, and the national language is Bangla. This predominantly monolingual identity of the nation is emphasised in its nationalist discourses. Significantly enough, Bangla has survived major linguistic threat and consolidated its presence in the nation's identity building in its both pre- and post-independent periods. Right after the creation of Pakistan in 1947, the Pakistani rulers attempted to impose Urdu as the sole state language of Pakistan-ignoring the reality that the Bangalees of East Pakistan were the majority among the entire population. This drew instant protests from the students, intellectuals, and socio-cultural activists of East Pakistan which was predominantly pioneered by the students of Dhaka University. A series of turbulent events led to the 21st of February 1952 when Dhaka University students came up with mass procession on the streets that witnessed a brutal oppression by the police. Numerous students were killed as the police opened fire. The language movement of 1952 became the new identity for Bangalees (then East Pakistanis) and introduced a tremendous sense of nationalism. The identity and sense of nationalism kept the nation united in the liberation war of 1971. Therefore, Bangla has continued to be the symbol of solidarity and national identity after independence.

However, the general presence of English in Bangladesh and its integration into the academic curricula have their roots in the colonial past. Like many other British colonial countries, English first came in contact with the people of this Indian sub-continent through the British Colony. British had left in 1947; however, the Indian sub-continent still bears the legacy of British colonial norms and values, including the language of English. As a matter of fact, while the British were ruling, English was used highly in political discourses, and it was lingua franca for the British to communicate with the elites of the region. Misra, as quoted in Islam \& Hashim (2019) (p. 248), noted that English was used in all formal domains such as administration and education. 
Following that, during the Pakistani regime, English continued to be widely used as a recognised state language with the status of second language (Rahman \& Pandian, 2018a, 2018b). The article 214 of the Pakistan constitution 1956 accepted English as the official language for 20 years (Khatun, 1992, p. 85).

After the independence of Bangladesh in 1971, the then Head of the State Sheikh Mujibur Rahman adopted the policy of 'one state one language', although several minor ethnic groups were inhabiting in this land (Rahman, 2010). The constitution of the People's Republic of Bangladesh, adopted in 1972, accepted Bangla as the state language through article 3. This policy was widely hailed politically although it was a similar act that once Pakistanis committed against Bengalis by trying to impose Urdu as the state language of Pakistan (East and West). However, the state attempt to expand the use of Bengali came at its expense. The adopted constitutional act narrowed the use of English in the official, social, and educational spectrums of Bangladesh and elevated the national language Bangla to a disproportionately higher level, which was to be used, practical or not, in all public domains which resulted in a severe lack in English proficiency among the people in general (Hamid \& Baldauf, 2014). Observing the conflict between English and Bangla languages in the state policy of post-independence Bangladesh, Hamid (2011) observed that the promotion of one was believed to be the demotion of the other. However, it is to be mentioned that, although teaching in Bengali was linked to the consolidation of national identity (Hoque, 2008, p. 1) in Bangladesh, a significant knowledge of English never lost its relevance because of its gatekeeping power to global education, career opportunity, and international exchanges.

\section{English in education policy: access and equity}

As it has been mentioned earlier, following the independence in 1971, Bangla received the status of national language through the compilation of the constitution in 1972 (section 3, The Constitution of the People's Republic of Bangladesh). In section 153(2) of the constitution, Bangla has also been given priority for the acceptance of Bangla version of the constitution at the time of any probable conflict between Bangla and English versions. Bangla was also given higher prestige in all domains of the society, primarily in education, which was not pragmatic at that time, since the outcome of the policy was a drop of English proficiency among the learner community. It also resulted in the automatic digression of English from the second language to a foreign language (Hamid \& Baldauf, 2014). Hamid (2010) further highlighted the dearth of quality in English language teaching (ELT) caused by the inconsistent language policy and planning (see Table 1). Bangladesh does not have a clear and planned language policy, and it has always been persistent (Rahman \& Pandian, 2018a, 2018b). As a result, a gap between policy and language practice exists in Bangladesh.

The newly adopted language in education policies explicitly indicated the significance of English in Bangladesh and language proficiency for its people. In line with the policy, communicative language teaching (CLT)-based curriculum reform took place in the mid-nineties, replacing the traditional grammar-translation method (GTM)-based language teaching, initially in secondary schools and later in all other levels (Rahman \& Pandian, 2018a, 2018b). Kaplan and Baldauf's (2003) language-in-education planning (LEP) framework consisted of seven key aspects of policy development: access policy, curriculum policy, method and material policy, personnel policy, resourcing policy, 
Table 1 Chronological summary of English in education policies

Education policies and commission
reports
1974 Bangladesh Education Commission
1976 English Teaching Taskforce
Commission
1988 Bangladesh National Education
Commission

1991 National Curriculum Committee

2000 National Education Policy

2003 National Education Commission

2010 National Education Policy
The position of English and English education

English language is given priority as a foreign language, to be taught from class 6 .

General emphasis on the English language.

English language to be taught either in class 3 or class 6 , subject to availability of English teachers.

Grade 3 suggested as a recommended starting point for English language education.

Grade 6 suggested as a uniform starting point for English language education.

English language education introduced in class 3.

English language was introduced as a compulsory subject in class 1 (1992).

English language set as a medium of instruction for kindergartens.

Curriculum and all text material used in kindergarten translated into English.

Introduction of English language as an extra subject from class 1 to 2 and as a compulsory subject from class 3

Along with Bengali, English language could be a medium of instruction from the secondary level (class 7).

Emphasis on English language as a medium of the instruction at the tertiary level.

Re-emphasis on English language learning from the primary level.

One objective of primary education to acquaint learners to English language skills as a foreign language.

Emphasis on rebuilding the overall English language curriculum.

Emphasis on organising foreign training for trainers of Primary

Teachers Institute (PTI) and National Academy for Primary

Education (NAPE) and local training for all secondary school teachers to improve English education.

Emphasis on introducing a 6-month English language course at the tertiary level.

English language was recognised as an essential tool to building a knowledge-based society.

Emphasis on English language writing and speaking from the very beginning of primary education.

English language to be set as compulsory subject adopted in all streams from the secondary level.

English language as a medium of instruction could be introduced from the secondary level.

Emphasis on appointing adequate number of English language teachers at the secondary level.

English language to be a compulsory subject in all colleges and universities.

English language (along with Bengali) to be the mediums of instruction at the tertiary level.

Emphasis on the need to translate books written in English to Bengali.

Adapted from Chowdhury and Kabir (2014, p. 10) and Rahman and Pandian (2018a, 2018b, pp. 895-896)

community policy, and evaluation policy. The English education policy reform from GTM to CLT was needed to be backed by clear planning and preparation (Hamid \& Honan, 2012). But, in the case of the policy reforms, a lack of substantial planning is 
evident (Rahman, 2015). Through further conceptualisation of the problem, these issues related to policy and planning have been discussed under the following sections: implementation of CLT, testing and assessment, and teacher education. In this section, two core elements of language in education policy in Bangladesh, which are intricately interconnected to each other, language access policy, and resourcing policy have been discussed in association with the contributory factors to the policy adaptation.

\section{English access and resourcing policy}

According to Kaplan and Baldauf (2003), access policy means who will learn what language and when. On the other hand, they conceptualised the language resourcing policy as the financing of language education (Kaplan \& Baldauf 2003). Currently, English is taught from grade 1 among 6-years-old learners. If access to English brings positive benefits to individuals, then English should be made equally accessible to all citizens (Rahman \& Pandian, 2018a, 2018b). However, English language teaching was not carefully planned since the quality of teaching and teachers is not equal and is poor across the country (Hamid \& Erling, 2016). Besides, most of the primary schools across the country are inadequately resourced, and lack of English teachers robs all aspirations (Haq, 2004). Furthermore, according to Hamid and Baldauf (2011), language access policy has created social inequity within the population since access to English is not equal in rural and urban areas. To make it worse, English medium schools get exclusive access to English with the bare minimum use of Bangla. Consequently, the emergence of English medium schools in the cities has contributed to the inequality to a large extent (Hamid, 2016; Hamid, Sussex, \& Khan, 2009). The urban students often go to English medium schools and receive their education in English (Mousumi \& Kusakabe, 2017). Thus, the level of their proficiency is higher compared to the Bangla medium students who study in public and private schools.

\section{Instrumental factors of English language policy adaptation}

The basis of the access policy initiation and the management of resourcing policy is not specific. Frequently, policymakers speak about the role of English learning to benefit from globalisation and to mobilise economic advancement (Hamid, 2010; Hamid, Nguyen, \& Baldauf, 2013) and suggest that students will be able to learn better if they start early (Rahman \& Pandian, 2018a, 2018b). However, the relationship between competence in English language and economic development is not always linear (Rahman, Singh, \& Karim, 2018b). Instead, it often times becomes a burden for a developing country such as Bangladesh to supply enough resources to facilitate English language education from grade 1 (Hamid \& Erling, 2016). Furthermore, it is often perceived as beneficial for the learners to start formal language learning early (Rahman \& Pandian, 2018a, 2018b), which policymakers often present as a justification. Incongruent to this simplified view, the current findings in the field of SLA are not definitive (Zein, 2017). It is, therefore, hard to justify such policy adaptation. Other than acquiring pronunciation, early starters of language are not substantially advantaged over the late starters (Rahman, Pandian, Karim, \& Shahed, 2017).

In evidence, none of the arguments is substantial enough to adopt such an early introduction of English language, and it eventually aggravates the provision of scarce educational resources (Rahman \& Pandian, 2018a, 2018b). Therefore, many English 
education researchers based in Bangladesh question the policy adaptation (Chowdhury \& Kabir, 2014; Hamid \& Honan, 2012). Vicious interest behind these policy adaptations is clear since they are not adopted based on the needs but due to the prescribed notion by the donors and non-government organisations (NGOs) (Kabir \& Chowdhury, 2017). Often, these policies are forced on the country and the policymakers by external stakeholders to import English language teaching as a product (Hamid, 2010; Hamid et al,, 2013). Bangladesh's English language policy and planning are highly influenced by supra-national factors, and actors such as international donor agencies, and sub-national actor such as NGOs. They work mostly in the form of language teaching and teacher development programmes (a brief description of these programmes has been provided in teachers' professional development section). Nevertheless, in reference to the unique relationship between developing aid and English language policy and planning in Bangladesh, Erling (2017) suggested that thoughtful initiatives can make more significant contributions to the holistic development and social justice in the context.

\section{Implementation of CLT: curriculum, method, and textbook}

By replacing traditional GTM by CLT, the Ministry of Education (MoE) had decided to reform the curriculum, methodology, textbook, and assessment system to ensure the development of English language learning and teaching in the country. The reform was implemented by the English Language Teaching Improvement Program (ELTIP), with the support of MoE and British Council (Karim, Mohamed, Ismail, \& Rahman, 2018). Despite its beginning with lots of promises, CLT has not been implemented as it was intended in the curriculum (Ali \& Walker, 2014; Chowdhury \& Kabir, 2014; Hamid \& Baldauf, 2008; Rahman \& Pandian, 2018a, 2018b). Several issues have contributed to the current problem associated with CLT implementation. Among them, factors associated with teachers and teaching practices are reported in the existing literature frequently (Ali \& Walker, 2014; Rahman \& Pandian, 2018a, 2018b; Rahman, Pandian, \& Kaur, 2018a).

According to Fullan's (2007) curricular innovation model, multiple factors contribute to teachers' implementation of the curriculum. Among these factors, characteristics of curriculum innovation are discussed in this section. They are (a) unacknowledged teachers' needs, (b) lack in curriculum clarity and complexity associated with curriculum, and (c) quality and practicality of textbook and other materials.

Curriculum development and implementation is a top-down process in the context of Bangladesh (Rahman, Pandian, \& Kaur, 2018a). As a result, teachers do not get the opportunity to express their views (Ali \& Walker, 2014). It is understandable that teachers are skilful in teaching through GTM method since they have the experience of utilising the method in the classroom. With the CLT innovation, teachers' needs were overlooked, and to an extent, it was imposed on them. Teachers' needs are identified as qualification and training (Farooqui, 2014; Khan, 2011), teaching methods and strategies (Ahmed, 2018; Jahan, 2008; Khan, 2011), managing large size class (Adhikari, 2011; Akbari, 2015), lack of effective teaching materials (Chowdhury \& Le Ha, 2008), and professional development (Anwaruddin, 2016) to implement the communicative approach in the context of Bangladesh. In addition, the reality of the classroom has certainly been ignored by the policymakers since there is an existing gap of 
communication between policymakers and implementers (Rahman \& Pandian, 2018a, 2018b). Studies conducted by Kirkwood and Rae (2011) and Kirkwood (2013) report that English in Action (EIA), a nationwide English development programme, has conducted the baseline studies to understand the ELT situation in primary and secondary schools, and based on that, they are working to improve the English language curriculum. However, they did not reveal the study population and the sites of data collection, e.g. school or district. Thus, it cannot be generalised that a representative number of teachers participated in terms of all demographic criteria to inform their needs.

A curriculum that is implemented in a top-down manner lacks clarity and creates complexity (Fullan, 2007). In their study, Das, Shaheen, Shrestha, Rahman, and Khan (2014) found that both English teachers and head teachers of the investigated schools lack any clear understanding of the CLT curriculum and consequently have a mixed opinion about its implementation. Similarly, Rahman, Singh, and Pandian (2018c) found that teachers' belief and practice are not congruent to CLT, and their understanding of the curriculum differed. Understandably, NCTB had asked teachers to implement CLT curriculum that was new to them without any well-planned contextual analysis on the probable complexities that may arise. For instance, teacher-centred classroom is a crucial feature in the classroom of Bangladesh, and students' willingness to communicate is often low (Rahman, Pandian, \& Kaur, 2018a). Thus, naturally, CLT implementation would become tough in such contexts. In the same vein, Chowdhury and Le Ha (2008) questioned the appropriateness of CLT and its pedagogical suitability in a completely different Eastern context such as Bangladesh where the pedagogic practice is dominated by a teacher-centred approach. However, Shrestha's (2013) study reported an improvement in the situation. Teachers have mostly reported being aware of their roles in the communicative classroom (Shrestha, 2013). Therefore, given the few empirical studies available currently, it is important to scrutinise further the teachers' understanding of the curriculum that might unearth new insights.

The textbooks have been revised on several occasions to make them more authentic for each level of the students and their communicative needs. The term Communicative English is used to signify the communicative competence necessary for effective interaction with other people, primarily through speaking and listening. Adhikari (2011) reported that the ability to speak accurate, appropriate, and effective English is vital for meaningful interaction that ensures students' communicative competence in English. He also argued that through the instructional materials, the teacher should provide students with the ample opportunity to relate syntax (rules of grammar) and morphology (vocabulary) to semantics (meaning) and pragmatics (language use) by means of interactive activities during teaching speaking. Instructional materials development for learning speaking in the classroom must take into cognizance the internal factors such as the use of native language, age, exposure, innate phonetic ability, identity and language ego, and motivation while an external factor, for example, EFL context should not be excluded (Brown, 2001, p. 118). However, according to Kirkwood (2013), English for Today textbook hopelessly lacks the speaking and listening activities. In addition to this, a mismatch exists between the national English curriculum and internal organisation of the textbook as reported in Ali (2014). In his study, Ali (2014) further reported that the textbook lacks authenticity and communicative aspects in its content. Kirkwood and Rae (2011) found that grammatical and vocabulary selections 
are predominant in the primary and secondary English textbooks in Bangladesh instead of communicative activities. In an earlier study, Chowdhury and Le Ha (2008) found that the learning materials are not contextual, rather borrowed from abroad. However, a recent study conducted by Rahman, Pandian, and Kaur (2018a) found through content analysis that more communicative activities are incorporated in the new book, and lessons are more contextualised and authentic. However, this finding needs to be further validated through empirical evidences collected from teachers and students. Moreover, further studies should be conducted on the development and implementation of the English for Today textbook, considering the fact that a handful of studies have evaluated the CLT textbooks used at different levels in Bangladesh.

\section{Implementation of assessment reform}

The success of language policy and implementation of the curriculum depends mostly on the quality of assessment and testing (Das et al., 2014). According to Quader (2001), the new CLT assessment approach is facing resistance in implementation from different stakeholders including teachers. However, not many empirical studies have devotedly investigated the issues related to CLT assessment and testing (Ali et al., 2018). There is a close relationship between the failure in English language teaching, learning, or curriculum implementation and inappropriate assessment methods in the context of Bangladesh (Khan, 2010; Rahman et al., 2018a, b, c).

One of the critical issues of the current high-stakes nationwide language testing in the public examinations is the exclusion of the two vital language skills, speaking and listening, from the centralised exams (Al Amin \& Greenwood, 2018a, 2018b; Sultana, 2018). This conservative attitude to test setting causes reduction of the curriculum which is a clear indication that the assessment is not congruent with the national curriculum and the national language policy. It has been reported that authority pressurises teachers to teach only those areas of the curriculum contents that are recurrently considered to construct English test papers (Choudhury, 2010; Maniruzzaman \& Hoque, 2010). According to Ali et al. (2018), the tests are not consistent with the goal of the national English curricula and the English language education policy that seeks to develop students' communicative competence; thus, it is evident that the test setters are under the compulsion of incorporating the instruction of the policymakers. On that note, it can be argued clearly that the assessment methods lack validity, due to the existing gap between what it "intended to be taught and what is measured" (Das et al., 2014, p. 330). Therefore, further studies are required to evaluate the contents that are being tested in the high-stakes public examinations and how these tests are developed (Ali et al., 2018; Sultana, 2018).

The impact of high-stakes assessment has severe washback effects on English language teaching in Bangladesh (Sultana, 2018). The washback effect of the English examinations is noted in the test preparation of the students and teachers in achieving higher grade (see Khan, 2010). This particular phenomenon leads the students to memorise the course contents (Rahman et al., 2018a, b, c) and poses the potential danger of acquiring shadow education (Hamid et al., 2009). Moreover, since the two important skills, listening and speaking, are not assessed in the tests, teachers and students are unwilling to practice them in the classroom (Rahman \& Pandian, 2018a, 2018b). It is evident that the washback effect of assessment impacts several aspects of teaching and 
learning of English in Bangladesh. However, there is still a paucity of empirical studies given those handful of studies mentioned above. Thus, further empirical studies are needed to find out the impact of washback of testing on the different classroom practices carried out by the teachers and the learners.

\section{English language teacher education}

The paucity of English teacher in Bangladesh is not a tale of today; we can trace the root of this scarcity in history. After the partition of the sub-continent in 1947, a good number of English teachers decided to leave the country since they were Hindu (Alam, 2018), against the backdrop that they might face religious threats and would endure as a minority in the newly formed state based on religion. Educated in the British period, the remaining teachers mostly retired in the 1980s. Consequently, preceding two decades, the curriculum, as well as the pedagogy, had been affected adversely; less English was being taught to students by teachers who had learned less of it (Alam, 2018).

Admittedly, teacher education (TE) is an indispensable part for enriching teachers' dexterity (Karim et al., 2018) regardless of the subjects they teach. In addition, TE contributes in building teacher cognition and teacher identity that embeds the decisive factors which determine teachers' actions in the classroom. The aim of any teacher education programme is to attain teachers' change (Hargreaves \& Fullan, 1992). As such, it becomes conspicuous that TE has direct influences on teachers' classroom practices (Rahman et al., 2018a, b, c). Perceiving the potential outcomes of TE programmes, teachers, irrespective of preservice and in-service in nature, in different contexts have received different trainings and participated in various education programmes in order to be equipped with skills and strategies such as creating interactive atmosphere, deploying audio-visual aids, and employing diverse activities for engaging students. (Karim \& Mohamed, 2019).

Bangladesh, a vibrant EFL context (Ali \& Walker, 2014) that has undertaken TE programmes as the sole avenue to produce auxiliary forces which not only contribute to national economy but also power the global economy (Karim, Shahed, Rahman, \& Mohammad, 2019b), has been continuing TE and professional development programmes for English teachers in the form of preservice and in-service TE programmes. Graduate and postgraduate programmes in TESOL, TEFL, and ELT constitute preservice TE (Karim, Shahed, Mohamed, Rahman, \& Ismail, 2019a) while government initiated in-service teacher education programmes, Certificate in Education (C-in-Ed) and Bachelor of Education (B.Ed), shape the in-service training programmes in the context. Additionally, the country benefitted by the donor-aided training programmes for English teachers, namely English Language Teaching Improvement Project (ELTIP), English for Teaching, Teaching for English (ETTE), Teaching Quality Improvement in Secondary Education Project (TQI-SEP), Secondary Education Quality and Access Enhancement Project (SEQAEP), and English in Action (EIA) (Hamid, 2010). Typically, the donors that perform in Bangladesh are the Department for International Development (DfID), Canadian International Development Agency (CIDA), World Bank, and Asian Development Bank (ADB).

As regards the outcome, Karim et al. (2019a, 2019b) report the adequacy in terms of knowledge base that prevails in preservice TE programmes. Conversely, Hamid (2010) defined the knowledge imparted in C-in-Ed and B. Ed programmes as inadequate since the contents of these programmes exert limited focus on the practical aspects of 
English teaching. In the same vein, Hamid and Erling (2016) reported the limited outcome drawn from in-service training programmes although sufficient funds have been leveraged to run these programmes. For instance, Karim, Mohamed, and Rahman (2017), building on various framework on TE programme, reveal that EIA that incorporated mobile phone as a tool for teacher development is only concerned about teacher training with mobile learning and eluded training about mobile learning and technology integration. Thus, teachers' successful orientation to audio-visual aid in the classroom, which was a major aim of EIA, has miserably failed (see Anwaruddin, 2016 for details). On top of that, Karim et al. (2018) drew a vignette of synchronised hypocrisies that significantly belittle the operation, function, and outcome of the in-service training programmes in Bangladesh. Hamid (2010) also suggests the discrepancies present in in-service teacher training programmes in Bangladesh.

Notably, EIA being the last among the donor-funded teacher training programmes intended to implement CLT with the help of information and communications technology (ICT) (Al Amin \& Greenwood, 2018b). It has not only focused on large-scale English language teachers' training, but also conducted empirical studies as a proof of their success (Karim et al., 2018). In contrast to the abovementioned studies, EIA-funded studies reported successful reform of CLT curriculum and development in teachers' quality (see Kirkwood, 2013; Power, Shaheen, Solly, Woodward, \& Burton, 2012; Shohel \& Banks, 2010; Shrestha, 2013; Walsh et al., 2013). These studies reported a positive outlook in teachers' beliefs and practices which were aligned with the curriculum. However, these hyper-success claims made by the donor-funded multimillion English teacher training programmes are not supported by the recent studies (see Al Amin \& Greenwood, 2018a, 2018b; Anwaruddin, 2016; Karim \& Mohamed, 2019; Rahman et al., 2018a, 2018b, 2018c). To elaborate, these studies revealed several challenges pertinent to the TE programmes such as the rarity of training sessions, less opportunity for the rural teachers, shortage of teachers' trainers, ineffective training materials, and insufficient resources to instrumentalise EIA training devices (Karim \& Mohamed, 2019; Rahman et al., 2018a, b, c). Eventually, too many teachers of English lack basic language and pedagogical competencies even after attending EIA training which resulted in a limited implementation of CLT in Bangladesh.

\section{Implications and conclusion}

Considering the fact that Bangladesh is one of the largest English learning populations of the world, it is significant to study problems associated with English language education in the country (Chowdhury \& Kabir, 2014; Hamid, 2016). This article discussed the key issues linked with ELT in Bangladesh by reviewing relevant concurrent literature. Based on the thematic discussion above, several implications emerged concerning English language education in the country and future research.

English in Bangladesh is significant in many ways. In order to supply the global demand of skilled workforce, English language proficiency is imperative. However, for the achievement of enhanced English language proficiency, an exclusionary approach such as scrapping Bangla and other ethnic languages from language planning is never desirable. Therefore, this research calls for adopting a glocal approach in providing appropriate linguistic attention to mother tongue and English, where Bangla and other indigenous languages would hold the root of the culture in terms of language practices in education 
and society while English will provide the nation more opportunity in the global stage. A national consensus should be made recognising multilingualism in Bangladesh which is historically, socially, and culturally evident in the land of Bangladesh, although it is politically unacknowledged.

Apparently, Bangladesh has remained unsuccessful in attaining self-reliance in English language teaching. Although the problem is reported widely in popular opinion and empirical studies, policymakers are often reluctant in admitting the problem. MoE should acknowledge the complication created by their inconsistent policy formulation. To adopt a sustainable language policy, policymakers must revisit some of the policies objectively, sidelining the prescriptions of the donors, NGOs, or any other interest groups, and plan accordingly. Eventually, inclusive language policy and planning based on equity should be the objective.

Undoubtedly, the CLT curriculum is one of the most dominant language teaching approaches in the world today. However, integrating CLT into the curriculum requires pragmatic and judicious planning since in the context of Bangladesh, the implementation of CLT approach is competing with the traditional language teaching and learning culture. Therefore, policymakers should re-evaluate the relevance of the CLT approach in the curriculum in the context of Bangladesh. In addition, textbook and classroom resources should comply with the objectives of the CLT curriculum.

The existing morbidity of English language assessment in Bangladesh discussed above shows that the challenges are numerous. Because of the limited scope of this study, only a few which deserve immediate attention are presented here. First of all, the washback effect needs to be addressed seriously. Assessment practices are hard to change; however, if initiatives to change the current practices are not taken, they will remain unchanged which will ultimately preclude the adoption of time-appropriate learning styles by the students. Secondly, assessment methods must be compatible with the contemporary expectations of the real world. Hence, the policymakers must think of alternative forms of assessment, at least alternatives in assessment. Finally, emphasis on classroom-based assessment and its integration to the overall assessment scheme is essential as classroom plays a crucial role in successful language learning in an EFL context like Bangladesh. In fact, continuous formative assessment in the classroom helps students make their learning more sustainable.

Bangladesh needs to strengthen its teacher training capacity through local expertise and institutions, instead of relying heavily on donor-funded teacher development programmes. Of several teacher education-related problems discussed earlier in the article, accountability deserves special attention in the teacher education programmes in Bangladesh; otherwise, no initiative could fulfil their promises and use the fund effectively. Moreover, considering the lacklustre in these teacher education programmes, the current study calls for employing proper monitoring and guidance on prospective training programmes. Alternatively, the local training capacity building is a sustainable approach which possibly offers school-based training to the teachers through local training centres.

Further research in language education bears significance in the context of Bangladesh since the number of empirical studies found in the context is not adequate to generalise the problems. Moreover, as indicated earlier in each section of the discussion, inconclusive research findings and relatively unexplored areas in the context of the study warrant the necessity of further studies on the discussed issues. With an in-depth understanding of these 
issues, a valuable contribution could be made to policy adaptation and implementation in the context of ELT in Bangladesh.

\author{
Abbreviations \\ CLT: Communicative language teaching; ELT: English language teaching; GTM: Grammar-translation method; \\ SSC: Secondary School Certificate
}

Acknowledgements

Authors want to acknowledge the reviewers' insightful comments on the earlier version of the article.

\title{
Funding
}

The first author acknowledges the support of the Institute of Postgraduate Studies, Universiti Sains Malaysia, for the award of USM Fellowship.

\section{Availability of data and materials}

Not applicable.

\section{Authors' contributions}

MMR made substantial contributions to the study conception and design and acquisition (literature review), analysis, and interpretation of data. MSI, AK, TAC, MMR, and PMIS have contributed equally in the review of literature and analysis and involved in drafting the manuscript and revising it critically for important intellectual content. MKMS has given the final approval of the version to be submitted and published. All authors read and approved the final manuscript.

\section{Competing interests}

The authors declare that they have no competing interests.

\section{Publisher's Note}

Springer Nature remains neutral with regard to jurisdictional claims in published maps and institutional affiliations.

\section{Author details}

'School of Languages, Literacies and Translation, Universiti Sains Malaysia, Penang, Malaysia. ${ }^{2}$ School of Education, Universiti Teknologi Malaysia (UTM), Johor Bahru, Johor, Malaysia. ${ }^{3}$ Department of English, Independent University Bangladesh, Dhaka, Bangladesh. ${ }^{4}$ BRAC Institute of Languages, BRAC University, Dhaka, Bangladesh. ${ }^{5}$ School of Educational Studies, Universiti Sains Malaysia, Penang, Malaysia. ${ }^{6}$ Department of English, University of Asia Pacific (UAP), Dhaka, Bangladesh. ${ }^{7}$ School of Languages, Civilization and Philosophy (SLCP), Universiti Utara Malaysia, Sintok, Kedah, Malaysia. ${ }^{8}$ School of Humanities, Universiti Sains Malaysia, Penang, Malaysia. ${ }^{9}$ Department of English, Noakhali Science and Technology University, Noakhali, Bangladesh.

Received: 19 March 2019 Accepted: 6 May 2019

Published online: 05 June 2019

\section{References}

Adhikari, B. R. (2011). Teaching speaking in the Nepalese context: Problems and ways of overcoming them. Journal of NELTA, 15(1-2), 1-9. https://doi.org/10.3126/nelta.v15i1-2.4602.

Ahmed, M. K. (2018). Pedagogy in speaking: Challenges addressed by teacher-student in the ESL context. International Journal of Applied Linguistics and English Literature, 7(3), 97. https://doi.org/10.7575/aiac.ijalel.v.7n.3p.97.

Akbari, Z. (2015). Current challenges in teaching/learning English for EFL learners: The case of junior high school and high school. Procedia - Social and Behavioral Sciences, 199(Auqust 2015), 394-401. https://doi.org/10.1016/j.sbspro.2015.07.524.

Al Amin, M., \& Greenwood, J. (2018a). The examination system in Bangladesh and its impact: On curriculum, students, teachers and society. Language Testing in Asia, 8(1), 1-18. https://doi.org/10.1186/s40468-018-0060-9.

Al Amin, M., \& Greenwood, J. (2018b). The UN sustainable development goals and teacher development for effective English teaching in Bangladesh: A gap that needs bridging. Journal of Teacher Education for Sustainability, 20(2), 118-138. https:// doi.org/10.2478/jtes-2018-0019.

Alam, F. (2018). Revisioning English studies in Bangladesh in the age of globalisation and ELT. In Engaging in educational research (pp. 241-261). Singapore: Springer.

Ali, M. (2014). An evaluation of 'english for today : for classes 11-12' as a textbook for Bangladesh higher secondary education ( Hse ). In The English teacher, XLIII (pp. 1-18).

Ali, M., \& Walker, A. L. (2014). Bogged down ELT in Bangladesh: Problems and policy. English Today, 30(2), 33-38. https://doi. org/10.1017/S0266078414000108.

Ali, M. M., Hamid, M. O., \& Hardy, I. (2018). Ritualisation of testing: Problematising high-stakes English-language testing in Bangladesh. Compare: A Journal of Comparative and International Education, 00(00), 1-21. https://doi.org/10.1080/ 03057925.2018.1535890

Anwaruddin, S. M. (2016). ICT and language teacher development in the global south: A new materialist discourse analysis. Educational Studies. https://doi.org/10.1080/00131946.2016.1169183.

Brown, D. (2001). Teaching By Principles (2nd ed.). Longman: USA.

Choudhury, R. K. (2010). Appropriateness and relevancy of communicative language teaching (CLT) for Bangladesh:A perspective from Bangladeshi rural secondary school English teachers, (PhD thesis). New York: Columbia University.

Chowdhury, R., \& Kabir, A. H. (2014). Language wars: English education policy and practice in Bangladesh. Multilingual Education, 4(1), 21. https://doi.org/10.1186/s13616-014-0021-2. 
Chowdhury, R., \& Le Ha, P. (2008). Reflecting on Western TESOL training and communicative language teaching: Bangladeshi teachers' voices. Asia Pacific Journal of Education, 28(3), 305-316. https://doi.org/10.1080/02188790802236006.

Das, S., Shaheen, R., Shrestha, P., Rahman, A., \& Khan, R. (2014). Policy versus ground reality: Secondary English language assessment system in Bangladesh. Curriculum Journal, 25(3), 326-343. https://doi.org/10.1080/09585176. 2014.909323.

Erling, E. J. (2017). Language planning, English language education and development aid in Bangladesh. Current Issues in Language Planning, 18(4), 388-406. https://doi.org/10.1080/14664208.2017.1331496.

Farooqui, S. (2014). The struggle to teach in English: A case study in Bangladesh. Journal of Education and Human Development, 3(2), 441-457.

Fullan, M. (2007). Change theory as a force for school improvement. In Intelligent leadership. https://doi.org/10.1007/978-14020-6022-9_3.

Hamid, M. O. (2011). Planning for failure: English and language policy and planning. In Handbook of language and ethnic identity: The success-failure continuum in language and ethnic identity efforts (Vol. 2, p. 192).

Hamid, M. O. (2016). The linguistic market for English in Bangladesh. Current Issues in Language Planning, 17(1), 36-55. https:// doi.org/10.1080/14664208.2016.1105909.

Hamid, M. O., \& Baldauf, R. B. (2008). Will CLT bail out the bogged down ELT in Bangladesh? English Today, 24(3), 16-24. https://doi.org/10.1017/S0266078408000254.

Hamid, M. O., \& Baldauf, R. B. (2011). English and socio-economic disadvantage: Learner voices from rural Bangladesh. Language Learning Journal, 39(2), 201-217. https://doi.org/10.1080/09571736.2011.573687.

Hamid, M. O., \& Baldauf, R. B. (2014). Public-private domain distinction as an aspect of LPP frameworks: A case study of Bangladesh. Lanquage Problems and Lanquage Planning, 38(2), 192-210. https://doi.org/10.1075//plp.38.2.05ham.

Hamid, M. O., \& Honan, E. (2012). Communicative English in the primary classroom: Implications for English-in-education policy and practice in Bangladesh. Lanquage, Culture and Curriculum, 25(2), 139-156. https:/doi.org/10.1080/07908318.2012.678854.

Hamid, M. O., Nguyen, H. T. M., \& Baldauf, R. B. (2013). Medium of instruction in Asia: Context, processes and outcomes. Current Issues in Lanquage Planning, 14(1), 1-15. https://doi.org/10.1080/14664208.2013.792130.

Hamid, M. O., Sussex, R., \& Khan, A. (2009). Private tutoring in English for secondary school students in Bangladesh. TESOL Quarterly, 43(2), 281-308. https://doi.org/10.1002/j.1545-7249.2009.tb00168.x.

Hamid, O., \& Erling, E. J. (2016). English-in- education policy and planning in Bangladesh: A critical examination. In R. Kirkpatrick (Ed.), English language education policy in Asia (pp. 25-48). Switzerland: Springer International Publishing

Hamid, O. M. (2010). Globalisation, English for everyone and English teacher capacity: Language policy discourses and realities in Bangladesh. Current Issues in Language Planning, 11(4), 289-310. https://doi.org/10.1080/14664208.2011.532621.

Haq, M. (2004). A baseline survey of rural secondary schools: A quest for teaching-learning quality. Bangladesh Education Journal, 3(2), 31-54.

Hargreaves, A., \& Fullan, M. G. (1992). Understanding teacher development. New York: Teachers College Press.

Hoque, M. E. (2008). Strength for today and bright hope for tomorrow learner's strategies, preferences and styles in learning English as a Foreign language: A study on the preferences of higher secondary students in Bangladesh (Vol. 8, pp. 1-13).

Islam, M. N., \& Hashim, A. (2019). Historical evolution of English in Bangladesh. Journal of Language Teaching and Research, 10(2), 247-255.

Jahan, A. (2008). Teaching speaking skills at tertiary level in Bangladesh: An Empirical Study. DIU Journal of Business and Economics, 3(1), 155-171.

Kabir, A. H., \& Chowdhury, R. (2017). "Donor logic", NGOs, the ruling elite and the decolonisation of education in Bangladesh. In Governance, resistance and the post-colonial state: Management and state building. https:/doi.org/10.4324/9781315544168.

Kaplan, R. B., \& Baldauf, R. B., Jr. (2003). Language and language-in-education planning in the Pacific Basin. Springer Science \& Business Media: Dordrecht.

Karim, A., \& Mohamed, A. R. (2019). Examining the impact of an English in action training program on secondary-school English teachers ' classroom practice in Bangladesh examining the impact of an English in action training program on. Qualitative Report, 24(3), 441-469.

Karim, A., Mohamed, A. R., Ismail, S. A. M. M., \& Rahman, M. M. (2018). Organized hypocrisy in EFL teacher training programs. International Journal of Instruction, 11(2), 437-450. https://doi.org/10.12973/iji.2018.11230a.

Karim, A., Mohamed, A. R., \& Rahman, M. M. (2017). ElA- a teacher education project in Bangladesh: An analysis from diversified perspectives. International Journal of Instruction, 10(4). https://doi.org/10.12973/iji.2017.1044a.

Karim, A., Shahed, F. H., Mohamed, A. R., Rahman, M. M., \& Ismail, S. A. (2019a). Evaluation of the teacher education programs in EFL context: A testimony of student teachers' perspective. International Journal of Instruction, 12(1). https://doi.org/10. 29333/iji.2019.1219a.

Karim, A., Shahed, F. H., Rahman, M. M., \& Mohammad, A. R. (2019b). Revisiting innovations in ELT through online classes: An evaluation of the approaches of 10 minute school. Turkish Online Journal of Distance Education, (January), 148-266. https://doi.org/10.17718/tojde.522729.

Khan, I. A. (2011). Challenges of teaching/learning English and management challenges of teaching/learning English and management. Global Journal of Human Social Science, 11(8), 79-80.

Khan, R. (2010). English language assessment in Bangladesh: Developments and challenges. In Y. Moon \& B. Spolsky (Eds.), Language assessment in Asia: Local, regional or global? (pp. 121-157). South Korea: Asia TEFL.

Khatun, S. (1992). Development of primary education policy in Bangladesh. University of Dhaka. Dhaka: University of Dhaka.

Kirkwood, A. (2013). English for communication in Bangladesh: Baseline research to establish the pre-existing environment for the "English in Action" project. System, 41(3), 866-879. https://doi.org/10.1016/j.system.2013.09.002.

Kirkwood, A. T., \& Rae, J. (2011). A framework for evaluating qualitative changes in learners' experience and engagement: Developing communicative English teaching and learning in Bangladesh. Evaluation and Research in Education, 24(3), 203-216. https://doi.org/10.1080/09500790.2011.610504.

Maniruzzaman, M., \& Hoque, M. E. (2010). How does washback work on the EFL syllabus and curriculum? A case study at the HSC level in Bangladesh. Language in India, 10(12), 49-88.

Mousumi, M. A., \& Kusakabe, T. (2017). The dynamics of supply and demand chain of English-medium schools in Bangladesh. Globalisation, Societies and Education, 15(5), 679-693. https://doi.org/10.1080/14767724.2016.1223537. 
Power, T., Shaheen, R., Solly, M., Woodward, C., \& Burton, S. (2012). English in action: School based teacher development in Bangladesh. Curriculum Journal, 23(4), 503-529. https://doi.org/10.1080/09585176.2012.737539.

Quader, D. A. (2001). Reaction to innovation in a language teaching project. Journal of the Institute ofModern Languages, 5, 22.

Rahman, M. M., \& Pandian, A. (2018a). A critical investigation of English language teaching in Bangladesh: Unfulfilled expectations after two decades of communicative language teaching. English Today, 34(3), 43-49. https://doi.org/10. 1017/S026607841700061X.

Rahman, M. M., \& Pandian, A. (2018b). Social Sciences \& Humanities the chaotic English language policy and planning in Bangladesh: Areas of apprehension. Pertanika Journal of Social Sciences \& Humanities, 26(2), 893-908.

Rahman, M. M., Pandian, A., Karim, A., \& Shahed, F. H. (2017). Effect of age in second language acquisition: A critical review from the perspective of critical period hypothesis and ultimate attainment. International Journal of English Linguistics, 7(5), 1. https://doi.org/10.5539/ijel.v7n5p1.

Rahman, M. M., Pandian, A., \& Kaur, M. (2018a). Factors affecting teachers' implementation of communicative language teaching curriculum in secondary schools in Bangladesh. Qualitative Report, (5), 23.

Rahman, M. M., Singh, M. K. M., \& Karim, A. (2018b). English medium instruction innovation in higher education: Evidence from Asian contexts. Journal of Asia TEFL. https://doi.org/10.18823/asiatefl.2018.15.4.20.1156.

Rahman, M. M., Singh, M. K. M., \& Pandian, A. (2018c). Exploring ESL teacher beliefs and classroom practices of CLT: A case study. International Journal of Instruction, 11(1). https://doi.org/10.12973/iji.2018.11121a.

Rahman, S. (2015). English language policy initiatives and implementation in Bangladesh: Micro political issues. Asian EFL Journal, 88, 59-96.

Rahman, T. (2010). A multilingual language-in-education policy for indigenous minorities in Bangladesh: Challenges and possibilities. Current Issues in Language Planning, 11(4), 37-41. https://doi.org/10.1080/14664208.2010.537816.

Shohel, M. M. C., \& Banks, F. (2010). Teachers' professional development through the English in Action secondary teaching and learning programme in Bangladesh: Experience from the UCEP schools. Procedia-Social and Behavioral Sciences, 2(2), 5483-5494.

Shrestha, P. N. (2013). English language classroom practices: Bangladeshi primary school children's perceptions. RELC Journal, 44(2), 147-162. https://doi.org/10.1177/0033688213488466

Sultana, N. (2018). Test review of the English public examination at the secondary level in Bangladesh. Language Testing in Asia, 8(1), 1. https://doi.org/10.1186/s40468-018-0068-1.

Walsh, C. S., Power, T., Khatoon, M., Biswas, S. K., Paul, A. K., Sarkar, B. C., \& Griffiths, M. (2013). The "trainer in your pocket": Mobile phones within a teacher continuing professional development program in Bangladesh. Professional Development in Education, 39(2), 186-200. https://doi.org/10.1080/19415257.2013.766232.

Zein, M. S. (2017). To postpone or not to postpone? Examining access policy on early foreign language learning from second language acquisition and language planning and policy perspectives. Applied Linguistics Review, 8(4). https://doi.org/10. 1515/applirev-2016-1044.

\section{Submit your manuscript to a SpringerOpen ${ }^{\circ}$ journal and benefit from:}

- Convenient online submission

Rigorous peer review

- Open access: articles freely available online

High visibility within the field

- Retaining the copyright to your article

Submit your next manuscript at $\boldsymbol{\nabla}$ springeropen.com 